\title{
The Impact of Performance Appraisal Policy on Employee Performance - A Case Study of Guaranty Trust Bank in Nigeria
}

\author{
Michael A. Akinbowale \\ Dinesh C. Jinabhai \\ Melanie E. Lourens
}

Department of Human Resources Management, Faculty of Management Sciences Durban University of Technology, KwaZulu-Natal, Durban, South Africa E-mail: abiodunnus2002@yahoo.com

Doi:10.5901/mjss.2013.v4n14p677

\begin{abstract}
The research investigation focused on performance appraisal policy and its impact on employee performance in Guaranty Trust Bank in Nigeria. The aim of the study was to ascertain the extent to which the performance appraisal policy at Guaranty Bank contributed to employee performance. Arising out of the performance appraisal reviews, an important finding revealed that the training which employees received resulted in improved job performance. The performance appraisal reviews also showed that when feedback reports were effectively used they consequently improved employee performance. The research design was quantitative in nature and a closed ended structured questionnaire was used to gather the primary data. The survey method was used for all the employees of Guaranty Trust Bank in Nigeria. The questionnaire was administered to all 150 target respondents using the personal method and a high response rate of $100 \%$ was obtained. The data gathered were analyzed using the Statistical Program for Social Sciences (SPSS) for the statistical tests. The initial analysis involved the use of descriptive statistical tools. The main findings revealed that, employee participation in the performance appraisal was generally high and this increased job satisfaction and enhanced employee performance. The results also revealed that manager-subordinate interaction was very cordial and this boosted employee performance. Moreover, the majority of respondents preferred performance appraisal to be used regularly for career pathing in the organization. The study recommends a set of guidelines which could be used in improving the current performance appraisal policy and further boost employee performance.
\end{abstract}

Keywords: Performance, Appraisal, Policy, Impact, Employee, Performance.

\section{Introduction}

Performance appraisal is the strength of performance management, which in turn affects the organizational performance. It helps to identify and overcome the problems faced by the employees on his/her work (Mackey and Johnson, 2000:3). Although it has many benefits for the organization, Nurse (2005:1179) states that performance appraisal have the equal probability of having a bad impact on the organization as well as on employee performance.

According to Mackey and Johnson (2000:3), where the performance appraisal improves the work performance and employee satisfaction, it can also demotivate employees and leaves a bad impression on the good employees. Most of the employees do not approve of continuous performance appraisal and also consider it as a burdensome activity (Anderson, 2002:80). According to Kuvaas (2006:509) and Rudman (2003:437), a performance appraisal and employee appraisal is a method by which the job performance of an employee is evaluated (generally in terms of quality, quantity, cost and time) typically by the immediate line manager or supervisor. A performance appraisal is a part of the process of guiding and managing career development in both private and public sectors. It involves the task of obtaining, analyzing and recording information about the relative worth of an employee to the organization. Mani (2002:158) states that performance appraisal is an analysis of an employee's recent successes and failures, personal strengths and weaknesses and suitability for promotion or further training.

The most popular methods used in the performance appraisal process (Mackey and Johnson, 2000; Fletcher and Bailey, 2003; Bond and Fox, 2007) include the following:

- $\quad$ Management by objectives.

- 360-degree appraisal. 
- Behavioural observation scale.

- Behaviourally anchored rating scales.

According to Rasch (2004:410), performance appraisal has a positive and negative impact. Employees who receive a good score on his/her appraisal are generally motivated to perform well and maintain his/her performance. Positive feedback on appraisals gives employee a feeling of worth and value, especially when accompanied by salary increases. If a supervisor gives an employee a poor score on his/her appraisal, the employee may feel a loss of motivation in the workplace. Consequently, this can impact on the employee's performance (Cook and Crossman, 2004:527). Performance appraisal is important for employees at all levels throughout the organization. The parameters, the characteristics and the standard for evaluation may be different, but the fundamentals of performance appraisal are the same. But performance appraisal is more effectively used as the tools of managing employee performance (Anderson, 2002:132).

\section{The Problem Statement}

The importance of an effective performance appraisal policy cannot be over emphasized in the overall performance of an organization. Performance appraisal policy can have a profound effect on levels of employee motivation and satisfaction (Cook and Crossman, 2004:531). Performance appraisal policy has been known to provide employees with recognition for their work and efforts. Also, the power of social recognition as an incentive has been long noted and recognized (Wilson and Nutley, 2003:94).

The existence of performance appraisal policy indicates to employee that the organization is genuinely interested in the individual's performance and development. This alone can have a positive influence on the individual's sense of worth, commitment and belonging. In both public and private organizations, the issue of employee performance has attracted attention of practitioners and scholars such that there is a wealth of evidence that there exists a positive causal linkage between effective performance appraisal and employee performance (Nurse, 2005).

\section{Objectives of the study}

The primary aim of this study was to investigate performance appraisal policy and its impact on employee performance in Guaranty Trust Bank in Nigeria. This was achieved through the following objectives:

- To determine the effectiveness of the performance appraisal policy of Guaranty Trust Bank.

- To ascertain the extent to which the Guaranty Trust Bank's performance appraisal policy contributes to employee performance.

- To determine the expectations and responsibilities of the functions to be performed by the employees of Guaranty Trust Bank.

\section{Literature Review}

\subsection{Objectives of Performance Appraisal Policy}

Performance appraisal is a managerial process that links corporate objectives, performance standards and evaluation to which the performance reviews or performance appraisal are often applied (Pickette, 2003:237). In its broadest sense, performance appraisal serves three major purposes within an organization, namely, administration, development and communication (Scott and Einstein, 2001:113).

According to Anderson (2002:82), administrative functioning can be viewed as staffing, compensation and promotion along with the systems of reward and punishment. Moreover, development refers to the identification and potential for future performance which is linked to personal development planning. In addition, an effective performance appraisal policy aims to provide feedback to employees about their performance and future goals. Williams (2002:27) states that in a survey conducted by the Institute of Manpower studies, it was revealed that performance management had various aims, including improving organizational effectiveness, motivating employees and improving training and development. However, these were the critical aims documented by the designers of the performance appraisal policy. Performance appraisal policy can also be used as by an organization to guard against cases of wrongful dismissal 
(Wilson and Nutley, 2003:310). Approaches to performance appraisal policy ranges from relatively simple techniques, such as ranking and traits rating, to the more complex method of behaviourally anchored scales (Tyson and York, 2000:37). According to Scott and Einstein (2001:113), methods also vary with regard to temporal emphasis, either focusing on the rating and ranking or using management by objectives to provide a future focus.

\subsection{The Development and Design of Performance Appraisal Policy}

According to Williams (2002:3), for many organizations, the primary goal of performance appraisal policy is to improve employee and organizational performance. However, a potential problem with performance appraisal policy and possible cause of much dissatisfaction, is expecting too much from one appraisal policy. Rudman (2003:107) contends that a performance appraisal policy that is effective for developing employees may not be the best for determining pay increases. A properly designed performance appraisal policy can help achieve organizational objectives and enhance employee performance.

According to Tziner, Joanies and Murphy (2001:178), the basic purpose of a performance appraisal policy is to improve performance of employees, teams and the entire organization. Performance appraisal policy may also serve to assist in making administrative decisions concerning pay increases, transfers or terminations. In addition, performance appraisal policy should be legally defensible. Although a perfect performance appraisal policy does not exist, every policy should possess certain characteristics. Wilson and Western (2001:94) contend that an organization should seek an accurate assessment of performance that permits the development of a policy to improve employee performance. The policy must honestly inform employees of how they stand with the organization.

Cook and Crossman (2004:106) highlight that the fundamental objective of performance appraisal policy is to facilitate management in carrying out administrative decisions relating to promotions, dismissals, layoffs and pay increases. For example, the present performance of an employee is often the most significant consideration for determining whether or not to promote the employee. Managers must recognize that an employee's development is a continuous cycle of setting performance goals, assessing performance as to the accomplishment of the goals and then setting new higher goals (Nurse, 2005).

\subsection{Trends in the Development of Performance Appraisal Policy}

According to Tyson and York (2000:321), performance appraisal policy has gone through evolutionary trends which are necessary as events change and new innovations evolve. Mani (2002) claims that evaluating the performance of employees has presented several challenges to managers. Thus, in the quest for effective management, the performance appraisal technique has been changing.

Wilson and Western (2001:91) contend that earlier performance appraisal policies were concerned mainly with personality and character traits such that knowledge of job and performance were relegated to the background. This appraisal method made the problems of management more complex. According to Rudman (2003:109), casual or unsystematic as well as traditional trait appraisals suffered from lack of objectivity. Managers seem uneasy in appraising their subordinates because of the realization that they based their evaluation on subjective standards (Scott and Einstein, 2001:109).

\subsection{Determinants of Performance Appraisal Policy on Employee Performance}

Wilson and Nutley (2003:316) observed that the traditional rating policy focused attention on personal traits and job characteristics. Such personal traits included the ability to get along with the people, leadership, analytical competence, initiative, ingenuity, ability to carry through assignments and seeing that plans and instructions are carried out.

Boswell and Benson (2000:288) highlight that because trait appraisal requires the managers to pass judgement on the personal worth of the subordinate, it is very counter-productive. Further, it also led to stereotyping and thus made the appraisal exercises meaningless. According to Tziner, Joanies and Murphy (2001), performance appraisal based on personal trait inhibits the subordinates from expressing their own feelings. According to Lazear (2000), the systematic approach to performance appraisal involved the use of a generalized series of questions, brief written answers to posed questions on an open report with the minimum of guidance given to the appraiser. Although this policy provided systematic feedback of information, the degree of subjectivity and inadequacy of the information is enormous and counter-productive (Rudman, 2003:109). 
According to Scott and Einstein (2001:114), performance appraisal policy based on personal trait inhibits the subordinates from expressing their own feelings. Even when they do, the superior's position overrides the employees' responses. Consequently, situations like this make the work environment uncomfortable as there is lack of trust as performance appraisal results or evaluations are accepted with shortcomings.

\subsection{Importance of Performance Appraisal Policy on Employee Performance}

One of the key responsibilities of the manager in any organization is to evaluate the performance of his subordinates. The essence of the performance appraisal is to assess the employees' character, attitude, potentials and past performance on the job (Mani, 2002:142).

According to Perez and Falcon (2004:57), if the evaluation system is poor, it will not give adequate effect. Rater's problems like leniency or harshness error, central tendency error, personal bias error, contrast error are also affects the performance appraisal of an employee. Kuvaas (2006:510) states that the halo effect occurs when a manager feels that the employee is particularly good in one aspect of his/her role and awards a similar high assessment for all other areas without objective consideration. Conversely, where an employee has a serious fault or poor element of performance, this can sometimes result in unjustifiably reduced assessment of other areas (Simmons and Lovegrove, 2002:340).

Armstrong and Baron (2005:106) state that each employee should be evaluated by his supervisor and then discuss set objectives for the upcoming evaluation. This discussion should cover the review of overall progress, employee development interest and needs to concentrate on specific areas of development in order to review performance objectives and performance standard.

According to Cook and Crossman (2004), performance appraisals are important for employee motivation, attitude and behaviour development, communicating organizational aims and fostering positive relationships between management and employees. Performance appraisals provide a formal, recorded, regular review of an individual's performance and a plan for future development. In short, performance appraisals are vital for managing the performance of employees in the organization. To achieve the organization targets there is the need for the employee and manager to discuss targets to be achieved, so that the former is genuinely able to commit to the challenge (Perez and Falcon, 2004:58).

According to Rudman (2003:70), performance appraisal policy was viewed as the single largest factor contributing to the development of the organization. It gives ways to innovative thinking and a determined action to eliminate underperformance, unmotivated and poorly managed and trained employees. All of these start with making on an effective performance appraisal policy established within the organization (Fletcher and Bailey, 2003:398).

Anderson (2002:82) highlight that the regular and proper use of performance appraisal policy gives better results for an organization. Performance appraisal policy may present two faces, namely the positive and negative aspects. For its positive aspect, it aids the organization in building mechanisms that enhance performance among employees as they aim to reach the shared vision and objectives set as one body. This is more of a discretionary effort as it increases the performance of employees and strengthens their commitment and engagement to their shared goals. For its negative aspect, performance appraisal involves a policy of appraisal which is dreaded by several managers and most of the employees such that it undermines the performance of the employees to perform better. Hence, in such case, it is considered as an irrelevant process of performance appraisal policy (Kuvaas, 2006:504).

\subsection{Effects of Performance Appraisal Policy on Employee Performance}

According to Wilson and Western (2001), it is natural for employees to be affected by how well they score on a performance appraisal depending on the outcomes. Thus, the application of a performance appraisal policy can be either positive or negative. Employees who receive good scores on their performance appraisals are generally motivated to perform well and maintain their performance. Conversely, if a supervisor gives an employee a poor score on his/her appraisal, the employee may feel a loss of motivation in the workplace. Consequently, this can impact on the employee's performance (Kuvaas, 2006:504).

According to Rudman (2003:437), performance appraisal policy is a critical factor in an organization in enhancing the performance of the employee. Further, there is a strong connection between how firms manage their employees and the organizational results they achieve. Simmons and Lovegrove (2002:35) asserted that most organizations differed from the rest in organization structure, customer orientation and human resources. Erdogan (2002) states that human behaviour in organization have also shown that the most harmful thing to organizations is when managers are unable to 
relate to their employees. Boswell and Benson (2000:288) contend that the human nature is in constant need of recognition and when they are recognized, either positively or negatively, it spurs them to do more. It is contended that one of the instruments through which managers motivate their employees is the use of an effective performance appraisal policy.

Cook and Crossman (2004:530) highlight that an employee whose performance is under review often become defensive. Whenever employee performance is rated as less than the best or less than the level at which employee personally perceives his/her contribution, the manager is viewed as being biased. Disagreement about the contribution and performance ratings can create a conflict ridden situation that festers for months (Mani, 2002:142). Nurse (2005) states that negative feedback from performance appraisal policy not only fails to motivate the typical employee, but can also cause employees to perform worse. Only those employees who have a high degree of self-esteem appear to be stimulated by criticism to improve their performance (Anderson, 2002:91).

According to Worley (2003:20), an appraiser should delineate performance appraisal policy to an employee appraised and not as an opportunity to criticize. It is primarily a way for explaining what could be done better and how the employee should perform better in future. Boswell and Benson (2000:286) state that it is important that the appraiser be well informed and credible, as employees are more likely to view the performance appraisal policy as accurate and fair. Employees are likely to feel more satisfied with their performance appraisal results if they have the opportunity to talk freely and discuss their performance. It is also more likely that such employees will be better able to meet future performance goals (Scott and Einstein, 2001:113).

According to Armstrong and Baron (2005:16), when employees work together effectively and communicate appropriately, the result is continuous and sustainable improvement. Rudman (2003:437) states that to attain overall organizational excellence, individual employees need to work together to find areas where challenges exist, or where performance can be improved. Bond and Fox (2007) highlight that managers and employees can work together to identify related development opportunities. Tyson and York (2000:142) state that when employees understand how their individual roles function within the framework of a team, they can more effectively contribute to the entire organization.

\subsection{Performance Appraisal Policy in Guaranty Trust Bank in Nigeria}

Guaranty Trust Bank in Nigeria is one of Africa's foremost Banking groups. In order to support its overall objectives related to performance management, the bank moved from a paper-based to a computer-based process of performance appraisal policy. This was done to improve performance appraisal completion rates, policy reliability and overall performance appraisal quality, making the policy more reliable and reduce the time needed to complete performance appraisals. Performance appraisal policy as an ongoing process is firmly embedded in Guaranty Trust Bank's values. The performance appraisal policy aims to ensure that employee output and behaviour as well as business unit performance are aligned with strategic and financial objectives. Employees are taken through annual performance appraisals as they set annual performance and behavioural objectives. Guaranty Trust Bank, with the vision of becoming a leading housing solutions provider with superior financial strength is of the view that managing the performance of employees and utilization of abilities are critical for improving the Bank's efficiency. It is also a continuous increase in the value offered to customers, namely, the shareholders and partners.

\section{Research Methodology and Design}

According to William (2006:183), a research design can be viewed as the planning of any scientific research from the first to the last step. Furthermore, it is a specification of the most adequate operations to be performed in order to test a specific hypothesis under a given condition.

\subsection{Research Design}

The research will utilize a quantitative research approach. According to De Vaus (2002:97), quantitative research is an empirical research approach in which hypothesis testing is used to discover relationships and facts that are generalisable. A quantitative approach focuses on the study of samples and populations and relies heavily on numerical data and statistical analysis (Neuman, 2000:250). 


\subsection{Target Population}

According to Neuman (2000:199), a population is defined as the sum total of all units of analysis from which the sample is drawn. Guaranty Trust Bank in Nigeria is a commercial and third biggest Bank in Nigeria based in Victoria Island, Lagos with staff strength of 150 employees. The number of employees in Guaranty Trust Bank was obtained from the Human Resources Group. The target population in this research was all 150 employees in Guaranty Trust Bank in Nigeria.

\subsection{Data Collection Method}

Data was collected through a survey using questionnaires administered to all 150 employees at Guaranty Trust Bank. A covering letter was used to ensure that respondents were informed of the intentions and purpose for the research. The questionnaire were formulated and designed as simply and logically as possible for ease of understanding. The questionnaire was personally administered by the researcher to the 150 target respondents in Guaranty Trust Bank in Nigeria.

\subsection{Data Analysis}

All of the data was captured and then analysed using computer based statistical program i.e. Statistical Package for Social Sciences (SPSS) version 15 for Windows. The appropriate statistical tests were used to analyse the data.

\section{Analysis of Data and Discussion of Findings}

Table 6.1 Impact of Performance Appraisal Policy on Employee Performance ( $\mathrm{N}=150)$

\begin{tabular}{|l|l|l|}
\hline & FREQUENCY & PERCENTAGE \\
\hline Yes & 137 & $91.3 \%$ \\
\hline No & 13 & $8.7 \%$ \\
\hline TOTAL & 150 & $100 \%$ \\
\hline
\end{tabular}

Table 6.1 respectively illustrates that the majority of respondents (91.3\%) were of the opinion that performance appraisal policy had an impact on employees' performance and a small minority of respondents (8.7\%) were dissatisfied. According to Mani (2002:158), in many organizations, performance appraisal results are used, either directly or indirectly, to help determine reward outcomes. That is, the performance appraisal results are used to identify the potentially good performing employees who should receive financial benefits, bonuses and promotions. Mackey and Johnson (2000:328) assert that performance appraisal results are used to identify the poor or weak performers who may require some form of counseling, or in extreme cases, demotion and dismissal. Anderson (2002:32) suggests that if a supervisor gives an employee a poor score on his/her appraisal, the employee may feel a loss of motivation in the workplace. Consequently, this can impact on the employee's performance.

Table 6.2 Training and Development of the Job and its Impact on Employee Performance $(\mathrm{N}=150)$

\begin{tabular}{|l|l|l|}
\hline & FREQUENCY & PERCENTAGE \\
\hline Strongly Agree & 84 & $56.0 \%$ \\
\hline Agree & 53 & $35.3 \%$ \\
\hline Neither Disagree nor Agree & 11 & $7.3 \%$ \\
\hline Disagree & 1 & $0.7 \%$ \\
\hline Strongly Disagree & 1 & $0.7 \%$ \\
\hline TOTAL & 150 & $100 \%$ \\
\hline
\end{tabular}

Table 6.2 respectively illustrates that $91.3 \%$ of the respondents strongly agreed that the adequate training which employees received based on performance appraisal policy will result in improvement in employee performance while $7.3 \%$ neither disagreed nor agreed. Only a minor $1.4 \%$ of the respondents disagreed with this statement. Direct 
observation at the Guaranty Trust Bank in Nigeria revealed that employees tend to perform better on their job. Particularly when the training has to do with rectifying job deficiencies identified in the course of an assessment of the employee's performance. This finding is in line with the view of Simmons and Lovegrove (2002:42) noted in the literature review. These authors stressed that training helps to give employees greater competence and personal satisfaction from the experience of being able to perform a job well. Mani (2002:158) also contends that a lack of training of employees may cause discrepancies between expected and actual performance of the process and associated satisfaction. Overall, training should increase the effectiveness of the performance appraisal policy and lead to greater organisational success (Cook and Crossman, 2004:532).

Table 6.3 Expectations of Employee Performance $(\mathrm{N}=150)$

\begin{tabular}{|l|l|l|}
\hline & FREQUENCY & PERCENTAGE \\
\hline Strongly Agree & 74 & $49.3 \%$ \\
\hline Agree & 58 & $38.7 \%$ \\
\hline Neither Disagree nor Agree & 11 & $7.3 \%$ \\
\hline Disagree & 4 & $2.7 \%$ \\
\hline Strongly Disagree & 3 & $2.0 \%$ \\
\hline TOTAL & 150 & $100 \%$ \\
\hline
\end{tabular}

Table 6.3 respectively depicts that the majority of respondents (88.0\%) agreed that an important function of the performance appraisal policy should be to determine the expectations and responsibilities to be performed by the employees, while $7.3 \%$ neither disagreed nor agreed. Only a minor $4.7 \%$ of the respondents disagreed with this statement. According to Rudman (2003:432), organizations implement performance appraisal policies to track how well employees perform their duties in the workplace. Evaluating employee performance entails assessing their accomplishments, behaviours and efficiency over a specific period. Bond and Fox (2007:436) state that work assessments determine whether the employee qualifies for bonus, promotion or disciplinary action. Under the accomplishments category, supervisors measure the employees' performance, efficiency, effectiveness and quality of their work. Robbins and Coulter (2002:56) highlight that the way an employee behaves affects how his supervisor views his/her overall performance.

Table 6.4 Communication between Managers and Employees ( $N=150)$

\begin{tabular}{|c|c|c|}
\hline & FREQUENCY & PERCENTAGE \\
\hline Strongly Agree & 80 & $53.4 \%$ \\
\hline Agree & 53 & $35.3 \%$ \\
\hline Neither Disagree nor Agree & 11 & $7.3 \%$ \\
\hline Disagree & 4 & $2.7 \%$ \\
\hline Strongly Agree & 2 & $1.3 \%$ \\
\hline TOTAL & 150 & $100 \%$ \\
\hline
\end{tabular}

Table 6.4 respectively illustrates that the majority of respondents (88.7\%) agreed that an important function of performance appraisal policy should be to facilitate communication between employees and their managers, while $7.3 \%$ neither disagreed nor agreed. Only a marginal $4.0 \%$ of the respondents disagreed with this statement. Tyson and York (2000:115) assert that communication is the key to success in any relationship. When a lack of communication exists in the organizational setting it has the potential to cause significant problems between management and employees. If this absence of interaction persists in the workplace, matters typically go unaddressed. As a result conflict often arises and problems remain unresolved because of the absence of communication. A lack of verbal exchanges commonly increase resentments and this usually further escalates the situation (Freeman, 2002:41). Mani (2002:141) highlights that the 
performance appraisal policy should constitute an open communication, where both manager and employee state what should be done well and what needs improvement. A definitive way to improve communication between management and employees is for managers to create an open door policy to welcome any thoughts, comments, complaints or suggestions. When employees are encouraged to share their feelings, it gives a sense of empowerment where they feel comfortable making contact with their managers to voice their concerns (Dessler and Gary, 2000:321).

\subsection{Hypotheses Testing}

Mouton (2001:109) explains that observations or data can be interpreted by developing hypotheses or theories that explain observed patterns and trends in the data. Interpretation means associating the results and findings of the study to existing theoretical frameworks or models and showing whether these are supported or proven to be false by the new interpretation. The formulation of hypotheses is a fundamental principle in the scientific method and the purpose of hypothesis is to predict a relationship between variables that can be tested. The hypothesis, once formulated, can be accepted or rejected on the basis of the statistical tests (Goddard and Melville, 2006:69). According to Walliman (2004:253), an essential part of any empirical analysis is to analyze the large collection of raw data into meaningful information. There are many reasons for analyzing data which include testing hypotheses, forecasting, making comparisons, measuring and examining relationships (Gaur and Gaur, 2009:33).

Ho1 There is a significant relationship between the perceptions of employees towards performance appraisal and effective performance.

Table 6.5 Employees' Perception on Performance Appraisal Leads to Effective Performance $(\mathrm{N}=150)$

\begin{tabular}{|l|l|l|l|l|r|}
\hline \multirow{2}{*}{} & \multicolumn{3}{|l|}{ TOTAL } & \multirow{2}{*}{} \\
\cline { 2 - 6 } & \multicolumn{2}{|l|}{$\begin{array}{l}\text { POSITIVE } \\
\text { PERCEPTION }\end{array}$} & \multicolumn{2}{l|}{$\begin{array}{l}\text { NEGATIVE } \\
\text { PERCEPTION }\end{array}$} & \\
\hline YES & 56 & $69.1 \%$ & 49 & $71.0 \%$ & 105 \\
\hline NO & 25 & $30.9 \%$ & 20 & $29.0 \%$ & 45 \\
\hline TOTAL & 81 & $54 \%$ & 69 & $46 \%$ & 150 \\
\hline
\end{tabular}

* Pearson Chi -square $=0.063^{b}, \mathrm{df}=1$, Significance $p<0.05$.

A Pearson Chi-square test revealed a significant result $(p<0.05)$. A further analysis showed that the majority of respondents (69.1\%) affirmed that employees' perception on performance appraisal leads to effective performance. According to Fletcher (2008:63), the element of an effective performance appraisal policy is based on what effect the performance of employee determines compensation. Coens and Jenkins (2002:232) assert that effective performance appraisal policy consists of constructive feedback for improvement as well as recognition for good employee performance. The ability to address both within the performance appraisal enables a balanced employee assessment. However, both constructive feedback and recognition are requirements for determining employee skills and aptitude, as well as training and development needs.

$\mathrm{H}_{0}$ There is a significant relationship between the perceptions of employees towards performance appraisal and job performance.

Table 6.6 Employees' Perception towards Performance Appraisal Leads to Job Performance $(\mathrm{N}=150)$

\begin{tabular}{|l|l|l|l|l|l|}
\hline \multirow{2}{*}{} & \multicolumn{3}{|l|}{ TOTAL } \\
\cline { 2 - 5 } & \multicolumn{2}{|l|}{$\begin{array}{l}\text { POSITIVE } \\
\text { PERCEPTION }\end{array}$} & $\begin{array}{l}\text { NEGTVE } \\
\text { PERCEPTION }\end{array}$ & \\
\hline YES & 53 & $65.4 \%$ & 46 & $66.7 \%$ & 99 \\
\hline NO & 28 & $34.6 \%$ & 23 & $33.3 \%$ & 51 \\
\hline TOTAL & 81 & $54 \%$ & 69 & $\mathbf{4 6 \%}$ & 150 \\
\hline
\end{tabular}

* Pearson Chi-square $=0.025^{b}, \mathrm{df}=1$, Significance $p<0.05$. 
In relation to Table 6.6 the hypothesis tested, a Pearson Chi-square test revealed a highly significant result $(\mathrm{p}<0.05)$. A further analysis showed that the majority of respondents $(65.4 \%)$ affirmed that employees' perception towards performance appraisal leads to improved job performance. According to Tyson and York (2000:11), several criteria are needed in order to evaluate job performance of an employee accurately. In the view of Robbins and Coulter (2002:24), the data or information that managers receive on how well employees are performing their jobs can be of three different types. Trait-based information, Behaviour-based information and Result based information. Levinson (2005:230) indicates that trait-based information identifies a subjective character of the employee such as attitude, initiative or creativity. Behaviour-based evaluations of job performance focus on what is included in the job itself (Armstrong and Baron, 2005:2). Results are outcomes produced by the employee. Result based information consider employee accomplishment. For jobs in which measurement is easy and obvious, a results-based approach works well (Mello, 2010:294). The nature of job itself was found to be positively correlated with performance which indicates that satisfaction with amount of variety and challenge in one's job actually influence performance. The sense of job satisfaction, feeling important in eyes of others, realizing ones' competence and freedom to make decisions are positively related to employee performance (Levinson, 2005:230).

\section{Conclusion}

The findings demonstrated that the performance appraisal policy can be an effective tool in employee performance if it is perceived to be objective and fair. The findings also revealed that employee participation in the performance appraisal policy was high and this led to employee performance and perception of the process and outcome as being fair. This finding also confirmed the observations of Bond and Fox (2007:143) who highlight that employee performance was transparent in their evaluations and that they were treated fairly in compensation and promotion.

\section{Recommendations}

- The results of the study indicated that most employees preferred performance appraisals to be used for training and development purposes. It is recommended that managers should improve on the training and development needs analysis component of performance appraisal policy in order to meet the aspirations of employees. A well trained and developed workforce is required for increased employee performance and organizational growth. It would also lead to efficiency and effectiveness of organizational activities.

- Any changes made to ratings of employees during the performance appraisal process should be communicated clearly and early to all concerned. This would go a long way to prevent conflict situations and create a healthy atmosphere for team work.

- Methods of helping poor performers to improve upon their performance, such as counselling and job rotation as well as transfers should be put in place by top management as policy interventions.

- To be able to obtain a reliable performance appraisal policy of the employee, supervisors should make it a point of making periodic notes on each of the employees to be appraised. This is because, if one waits till the end of the period to do the performance appraisal policy, the tendency will be to forget some other important positive or negative behaviour the appraisee showed in the course of that period under review.

- Top management and managers, who conduct the performance appraisal needs to be equipped with methods of motivating employees through the performance appraisal policy. Kuvaas (2006:510) indicates that motivation is an important element to employee performance. Furthermore, performance appraisal policy creates a learning experience that motivates employees to develop themselves and improve on their performance.

\section{References}

Anderson, J.R. (2002). Measuring Human Capital: Performance Appraisal Effectiveness. Paper presented at the Human Resource Track Midwest Academy of Management Conference. Kansas City: Missouri.

Armstrong, M. \& Baron, A. (2005). Managing performance: Performance management in action. Chartered Institute of Personnel and Development.

London: Kogan.

Bond, T. \& Fox, C. (2007). Applying the Rasch Model: Fundamental Measurement in Human Sciences. $2^{\text {nd }}$ Edition. New Jersey: Lawrence Album Associates. 
Boswell, M. \& Benson, J. (2000). Employee Satisfaction with Performance Appraisal and Appraisers: The role of perceived appraisal use. Human Resources Development. 11(3): 283-299.

Burns, A.C. \& Bush, R.F. (2002). Marketing research: Online research applications. 4th Edition. New Jersey: Prentice Hall.

Cook, J. \& Crossman, A. (2004). Satisfaction with performance appraisal systems. Journal of Managerial Psychology. 19 (5): 526-541.

Creswell, J.W. (2003). Research Design: Qualitative, Quantitative and Mixed Methods Approaches. Thousand Oaks, CA: Sage Publications Inc.

Dessler, D. \& Gary, R. (2000). Human resources Management. 8th Edition. Harlow: Prentice Hall.

De Vaus, D.A. (2002). Survey in Social Science Research. $5^{\text {th }}$ Edition. Crow Nest, New South Wales: Allen and Unwin.

Erdogan, B. (2002). Antecedents and consequences of justice perceptions in performance appraisals. Human Resources Management Review. 23(12): 555-578.

Fletcher, C. \& Bailey, C. (2003). Assessing Self-awareness: Some Issues and Methods. Journal of Managerial Psychology. 18(5): 395404.

Fletcher, C. (2008). Appraisal, feedback and development: Managing performance review at work. $4^{\text {th }}$ Edition. Oxford: Routledge.

Freeman, J. (2002). How to improve the effectiveness of performance management and appraisal by overcoming the root cause of the problem. The Human Resources Management Guide Network [Online]. Available: http:www.hrmguide.com/performance. Date accessed: 17 December 2011.

Gaur, A.S. \& Gaur, S.S. (2009). Statistical methods for Practice and Research: a guide to data analysis using SPSS. $2^{\text {nd }}$ Edition. New Delhi: Sage Publications Ltd.

Goddard, W. \& Melville, S. (2006). Research Methodology. An Introduction. 2nd Edition. Lansdowne: Juta and Co. Ltd.

Kuvaas, B. (2006). Performance Appraisal Satisfaction and Employee outcomes; mediating and moderating roles of work motivation. International Journal of Human Resources Management. 17(3): 504-522.

Lazear, E.P. (2000). Performance Pay and Productivity. American Economic Review. 90(5): 1346-1361.

Levinson, H. (2005). Management by Whose Objectives. Harvard Business Review on Appraising Employee Performance. Harvard Business School Publishing. Boston: Allyn \& Bacon.

Mackey, K. \& Johnson, G. (2000). The Strategic Management of Human Resources in New Zealand. Auckland: Irwin/McGraw-Hill.

Mani, B. (2002). Performance appraisal systems, productivity, and motivation: A case study. Public Personnel Management. 31(19): 141-159.

Mello, J.A. (2010). Strategic Human Resources Management. $3^{\text {rd }}$ Edition. Mason, Ohio: South Western.

Mouton, J. (2001). How to succeed in your Masters and Doctoral Studies: A South African Guide and Resource Book. Pretoria: Van Schaik.

Neuman, W.L. (2000). Social Research Methods: Qualitative and Quantitative approaches. $4^{\text {th }}$ Edition. Boston: Allyn \& Bacon.

Nurse, L. (2005). Performance appraisal, employee development and organizational justice: exploring the linkages. The International Journal of Human Resource Management. 16(7): 1176-1194.

Perez, P.D. \& Falcon, J.M. (2004). The Influence of Human Resource Management in Savings Bank Performance. The Service Industrial Journal. 24(2): 51-66.

Pickette, L. (2003). Transforming the Annual Fiasco. Industrial and Commercial Training. 35(6): 237-240.

Rasch, L. (2004). Employee Performance Appraisal and the 95/5 Rule. Community College Journal of Research and Practice. 28(5): 407-414.

Robbins, S.P. \& Coulter, M. (2002). Management. $7^{\text {th }}$ Edition. Upper Saddle River, NJ: Prentice Hall.

Rudman, R. (2003). Human Resources Management in New Zealand. Auckland: Pearson Education New Zealand Limited.

Saunders, M., Lewis, P. \& Thornhill, A. (2003). $3^{\text {rd }}$ Edition. Research Methods for Business Students. Harlow: Prentice Hall.

Scott, S.G. \& Einstein, W.O. (2001). Strategic Performance Appraisal in Team-based Organizations: one size does not fit all. Academy of Management Executive. 15(2): 107-116.

Simmons, J.A. \& Lovegrove, I.W. (2002). Negotiating a research method's conceptual terrain: lessons from a stakeholder analysis perspective on performance appraisal in universities and Institutes. Paper presented at the European Conference on Research Methods in Business and management. Reading: Kidmore End.

Tyson, S. \& York, A. (2000). Essentials of Human Resources Management. $4^{\text {th }}$ Edition. Oxford: Jordan Hill.

Tziner, A., Joanies, C. \& Murphy, K. (2001). A Comparison of Three Methods of Performance Appraisal with Regard to Goal Properties, Goal Perceptions, and Rate Satisfaction. Group and Organisation Management. 25(13): 175-190.

Walliman, N. (2004). Your Research Project: A Step-by-step Guide for the first time Researcher. London: Sage Publications Ltd.

William, M.K.T. (2006). Research Methods Knowledge Base [Online]. Available: http:www.socialresearchmethods.net/kb/intreval.htm. Date accessed: 14 October 2010.

Wilson, F. \& Nutley, S. (2003). A Critical Look at Staff Appraisal: The Case of Women in Scottish Universities. Gender, Work and Organization. 10(3): 301-319.

Wilson, J.P. \& Western, S. (2001). Performance Appraisal: An Obstacle to Training and Development. Career Development International. 6(2): 93-99. 